\title{
On Becoming Faculty Librarians: Acculturation Problems and Remedies
} W. Bede Mitchell and Bruce Morton

\begin{abstract}
The acculturation of librarians to faculty librarian positions is compared and contrasted to the socialization process of the professoriate. Substantive differences in graduate library education and the attitudes it cultivates are discussed. Librarians are seen, for the most part, as being ill-prepared to assume peer roles within a university faculty. Suggestions are offered to remedy this dysfunctional pattern.
\end{abstract}

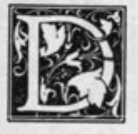

uring the past two decades there has been discussion ad nauseam in the library literature about the pros, cons, and mechanics of librarians performing as faculty.' The lack of consensus among librarians about the desirability of faculty status has had various consequences, not the least of which is impeding librarians' acculturation to the academic environment. Some evidence indicates that many academic librarians do not understand the fundamental tenets of being members of a faculty. ${ }^{2}$

Not surprisingly, the transition from student to professional is usually stressful in any profession. ${ }^{3}$ For librarians, however, the stress naturally inherent in the process of socialization to a new job and a new work environment is exacerbated by ingrained characteristics of education for librarianship, by the attitudes articulated in the literature of librarianship, and by reinforcement of both by more senior librarians.

Librarians who do not understand what it means to be faculty members find themselves uncomfortable and therefore at a disadvantage. They may find themselves unprepared or unwilling to carry out faculty responsibilities; if this is the case, they are likely to be unhappy or ineffective. The resultant ebb in morale may result in the declining performance of new and veteran librarians alike. Such factors could lead to short tenures and high staff turnover for newer library faculty. Indeed, a high turnover rate, whether it be because of frustrated expectations or because of not meeting performance criteria, is an indicator of ineffective socialization. ${ }^{4}$

The lack of consensus among librarians about faculty status seems to be rooted in two controversies. First, there continues to be disagreement over whether librarians qualify as faculty. Are their duties and responsibilities sufficiently scholarly, academic, and professional to warrant having the same rights and similar performance expectations as the instructional faculty? Officially, this issue was affirmatively resolved among librarians in the affirmative when the Association of College and Research Libraries (ACRL) adopted the "Standards for Faculty Status for College and University Librarians." ${ }^{5}$ The second controversy is whether the performance criteria for librarians should be identical to

W. Bede Mitchell is Associate Librarian for Public Services at Appalachian State University, Boone, North Carolina 28608, and Bruce Morton is Assistant Dean of Public Services for the library and a professor at Montana State University, Bozeman, Montana 59717-0332. 
that of the instructional faculty or modified to allow for differences in duties and schedules. In other words, are librarians faculty of a somewhat different sort? The ACRL "Standards for Faculty Status" state that librarians should be regularly and rigorously reviewed and that promotion and tenure provisions should be the same as those for the instructional faculty, but there is no explicit statement as to whether librarians' evaluation criteria should be identical to the instructional faculty's. The "Model Statement of Criteria and Procedures for Appointment, Promotion in Academic Rank, and Tenure for College and University Librarians" indicates general categories of performance, such as scholarship and effectiveness as a librarian, that should be considered when evaluating librarians for promotion or tenure, ${ }^{6}$ but because the "Model" is intended to propose only minimal criteria, it is restricted to general language that allows for substantial local interpretation.

\section{THE NATURE OF THE PROBLEM: ACCULTURATION TO WHAT?}

The "Model" and "Standards" provide little effective guidance to an academic librarian interested in learning about what might be specifically required in faculty status positions. At some institutions the performance criteria might be identical with the criteria used for evaluating instructional faculty, while elsewhere substantial differences may exist. It is important to understand that inadequate acculturation to the academic model and the role of faculty lead to other performance problems beyond the frequently expressed difficulties in meeting research requirements. Implicit in having faculty status rather than merely being faculty is an underlying assumption that there is somehow a difference and therein turns the worm of doubt. Being a member of the professoriate of a university or college faculty is a state of mind that transcends the niceties and formalities of employment. It is a commitment to a transcendent academic culture, to an intellectual community, and to the pursuit of inquiry. Thus, most faculty perform as they do not because they are made to, but because they want to and need to, for that is what they are about. The academic culture is selfselecting in this regard; those who do not conform are winnowed out.

Librarians new to librarianship and the academy may be justifiably confused about what to expect in a faculty appointment. The lack of consensus in the profession about faculty status and performance criteria cannot but help to contribute to undermining and impairing the acculturation of academic librarians to the faculty model. In contrast, colleagues in the nonlibrary faculty go through a socialization process when they study to become members of the professoriate. The experiences of graduate students in other fields are shaped by values and expectations that prepare them for their rights and responsibilities as faculty members. This is far less true in librarianship.

\section{THE PROCESS OF ACCULTURATION}

How do fledgling faculty members become acculturated to their new roles? A professional community like the professoriate produces its next generation by controlling the selection of professional trainees, sending recruits through a distinctive socialization process. ${ }^{7}$ Carol Shulman summarizes the faculty socialization process in her discussion of graduate schools, seeing the graduate experience as the period when the primary transmission of faculty values takes place. It is in graduate school that students learn that academics are a professional group that claims the right to regulate itself, determining its own methods and judging its own members. It is in graduate school that the importance of research and loyalty to one's discipline are stressed. The professional self-images of graduate faculties and their interest in advancing knowledge and their disciplines or professions dovetail with another central value of the academic model, academic freedom. ${ }^{8}$ As explained by Shulman, the academic model that is inculcated in graduate students consists of four tenets: (1) research is the primary focus of the university; (2) academic work 
requires peer judgment; (3) scholarship is a vocation in its own right; (4) the academic profession serves important social goals. ${ }^{9}$ These four points, in large part, comprise the state of mind that is characteristic of a member of the professoriate.

Shulman's academic model is consistent with the sources of integration that Burton Clark believes serve to make the professoriate a true community of scholars in spite of the superficial differences existing among the various disciplines. ${ }^{10}$ Clark cites academic freedom, scientific norms, scientific methodology, and ethics of scholarship as comprising a set of shared values that override differences among disciplinary faculties.

Sherlock and Morris have developed a professional-evolution paradigm that serves as a useful guide for examining how the scholarly values identified by Shulman and Clark are transmitted by graduate schools. In the Sherlock and Morris paradigm, socialization is an institutionalized sequence of processes that represent the collective judgment of a profession as to the best means of reproducing itself. The processes are intended to find the appropriate recruits (selection); isolate them from competing influences (sequestration); inculcate necessary knowledge (didactic instruction); develop skills, values, and role models (apprenticeship); motivate them to attain the profession's goals (sanctioning); certify those individuals who are demonstrably competent (certification); and launch the newly certified professional upon a career (sponsorship). ${ }^{11}$ There follows a discussion of this sequence of processes and the inherent difficulties as they specifically apply to librarianship.

\section{Selection}

Selection of appropriate candidates for the professoriate involves both self-selection and recruitment. Interested undergraduate students develop an understanding and identification with subject content, jargon, and research paradigms. Those who are not interested in terminating their formal higher education with a bachelor's degree may choose to apply for admission into graduate school (self-selection), thus con- stituting a candidate pool from which the graduate schools will accept those they believe are the most promising students, based upon past performance, degree of present commitment, and level of demand for new professionals in the field. Given this pattern, librarianship as a discipline is at a distinct disadvantage in that most undergraduate library education programs are not designed to serve as feed-in programs for library graduate schools. ${ }^{12}$ Few new graduate students in library science have entered the program because they have been stimulated by undergraduate curricular experience, but rather because they think they will find it appealing on the basis of the experience they have had in a place - the library. The fact that the performer (the librarian) is named on the basis of place, rather than on what is done in the place (assembling knowledge, creating pathways and gateways to knowledge, providing introduction to knowledge or to the pathways and gateways, etc.) skews attitudes and focus away from the intellectual fabric of the enterprise.

\section{Sequestration}

The sequestration or isolation aspect of socialization attempts to eliminate influences, usually of an extracurricular nature, that interfere with students' learning the desired professional model and values. Sherlock and Morris speak of selective patterning of experience that promotes the role of professional student and subordinates other sources of identity. It seems intuitive that this selective patterning of experience is most effective with full-time students in that "the intensity of any socializing experience is probably related to the degree of separation, for separated settings are able to reduce potentially conflicting influences. They can command more of the recruits' time and energy." ${ }^{\prime 13}$ Evidence suggests that the process of sequestration in graduate education for academic librarianship falls short. ${ }^{14}$

\section{Instruction and Apprenticeship}

The inculcation of necessary knowledge is the formal transmission of a discipline's theory and knowledge base 
through classroom instruction, study assignments, and laboratory exercises. This aspect of socialization, the phase of didactic instruction, contributes significantly to the attrition of marginal or uncommitted students. Closely related to didactic instruction is apprenticeship instruction, a phase of socialization in which graduate students gain firsthand experience in teaching and research. Didactic instruction and apprenticeship are the phases of socialization where the process is explicit. According to Sherlock and Morris, apprenticeship is one of the most important aspects of socialization because "the hallmarks of a professional are acquired in the apprenticeship period. It is at this stage that concerns with regard to actual clients, ethical and technical problems, and career plans emerge as important preoccupations." 15

Of course, the key nonlibrary faculty roles are teaching and research; for academic librarians librarianship may be regarded and performed as analogous to those roles. Rather than thinking passively of librarianship as the organizing and retrieving of knowledge, librarians should think of it in dynamic terms: assembling knowledge, creating pathways and gateways to knowledge, and providing introductions to knowledge or to the pathway and gateways. In many disciplines, students have ample opportunities as graduate teaching assistants to practice both literally and figuratively their trade didactically. For the most part, new librarians in the academic setting are no more prepared for the demands of instructional programs or collection development than are nonlibrary faculty who did not have the opportunity to train as teaching assistants while in graduate school.

Research skills are mastered through the highly structured experience of designing, conducting, writing, and defending a master's thesis or doctoral dissertation. Such apprenticeship experiences are carefully tailored to suit the variations of knowledge contexts that exist between disciplines. The research methods and problem-solving techniques in a discipline tend to dictate how faculty interact with students and colleagues, and hence the apprenticeship period for aspiring faculty will reflect those relationships and working styles. For example, graduate students in the pure sciences (e.g., physics, chemistry, biology) often become members of a collaborative research enterprise in which their research supervisor controls their research theme and dictates the schedules and performance habits to which the students must abide. This approach works well in the pure sciences because problems tend to be easily divisible. Thus, an effective method of solving the problem is by synthesizing the solutions to the various sub-problems found by a team of researchers, with teamwork naturally implying conformity to group norms and a readiness to accept the authority of the team leader. ${ }^{16}$

\section{Colleagues in the nonlibrary faculty go through a socialization process when they study to become members of the professoriate.}

This contrasts strongly with the way research tends to be done in disciplines like history or anthropology, in which collaboration is less frequent because, as Tony Becher has observed, "problems tend to be broadly defined and not readily amenable to subdivision. . . ." 17 The individual approach to research in such disciplines is naturally reflected in the way doctoral candidates conduct their dissertation studies. Becker stated that "far from being regarded as employees, they are treated like self-employed persons or individuals of independent means. They are not required to observe any firm rules of attendance .... Contact with their research supervisors is usually sporadic." 18

The apprenticeship experience is intended to give students the opportunity to gain hands-on experience and work with role models, both in teaching and research. By contrast, students in librarianship rarely have teaching experiences because there are not many under- 
graduate library classes for them to teach, and only a very few of the students will become professors of librarianship. Instead, it seems more appropriate for library students to serve internships that enable them to perform in a library, doing whatever the students think they may do when they graduate, such as cataloging or working in a reference department. Such internships offer the opportunities for hands-on experience and for working with role models. However, students seeking the M.L.S. do not conduct a dissertation research project because the M.L.S. program is not designed to produce researchers. Although some M.L.S. programs require a master's thesis, such projects are not comparable to doctoral research either in rigor or substance, and even then, most programs permit the graduate student to opt for more courses in lieu of the thesis. Therefore, academic librarians usually lack socialization to research that other faculty gained in graduate school. As a result, librarians not only are unprepared to meet research requirements found in promotion and tenure criteria but also lack an empathetic appreciation for the rigors and methodology of research, which may be reflected in decisions about service policies. These very weaknesses are the primary reasons why a graduate degree in addition to the M.L.S. is so desirable for academic librarians. The subject expertise gained from the additional graduate degree is a residual benefit. ${ }^{19}$ William G. Jones asserts that "another advanced degree would, however, assure that librarians who provide services to scholars understand the intellectual norms of disciplines recognized within the scholarly community and the importance of primary and secondary sources in them." ${ }^{\prime 20}$

\section{Sanctioning}

Throughout every step of the acculturation process, performance is influenced by rewards and punishments. Such performance sanctioning takes place mostly in didactic instruction and apprenticeship, but at any point students' appearance, demeanor, and behavior may also be judged. Library schools are no less inclined to sanction classroom or behavioral performance than are other professional schools. However, little if any evidence exists that library schools attempt to teach prospective academic librarians to think or act as faculty members or to relate with nonlibrary faculty as colleagues. It seems that the prevailing attitude is that they are training professionals, not scholars. Emphasis is placed on models that present nonlibrary faculty to be clients, or that describe librarians as playing important but supportive or subsidiary educational roles to the nonlibrary instructional faculty. This is consistent with the service model that pervades library education, regardless of tracking into public, special, or academic librarianship. The emphasis on service-the server and the served-severely handicaps librarians who will eventually find themselves assuming positions where the collegiality of academic peer relationships with nonlibrary faculty is an expected norm. Library education unintentionally inculcates librarian stereotypes in the prospective academic librarian..$^{21}$ All members of the professoriate are professionals. The term professional should not be conveniently misconstrued by librarians as one of exclusivity; just the opposite is true.

\section{Certification and Sponsorship}

The final socialization phases are certification and sponsorship. Students receive a school's certification, usually in the form of a degree, once academic requirements have been met satisfactorily. "Certification ... provides visible and creditable evidence that the individual is a professional in the legal sense of the word." 22 Certification is also intended to contribute to the sense of professional identity that the socialization process is meant to create. Sponsorship works as a continuing influence on professionals after they have graduated through such acts as collaboration or recommendations to colleagues via the old-boy or -girl network. Such activities include job placement efforts and assistance in gaining desired postgraduate internships or fellowships. Sherlock and Morris note that "differential sponsorship exists so 
that the best positions are not equally available." 23 Clearly, certification and sponsorship can be powerful tools for controlling the quality of new professionals. Students who are weak performers or who do not conform run the risk of not receiving certification, and those marginal students who do obtain certification may receive little in the way of sponsorship, thus achieving limited professional opportunities.

\section{Mentoring}

Even in the best of circumstances preparatory education does not completely prepare the new faculty member for the workplace. One library school professor used to say in a mixture of truth and hyperbole that the M.L.S. would only get one past the first day on the job. More senior faculty colleagues must be prepared to provide mentoring to a junior colleague. ${ }^{24}$ Mentoring is often assumed to be synonymous with looking out for someone. This is simplistically incorrect and will inevitably lead to shortchanging those in need of mentoring. It is essential that library faculty, as part of their professional development, learn what it is to be a mentor. They must understand the needs of faculty, based not on an articulation of those needs by the novice, but rather on their own knowledge of librarianship, the local institution, and academe in general, and their experience in all three. They must expect to be friend, career guide, information source, and intellectual guide. ${ }^{25}$ If senior librarians do not have an adequate understanding of these fundamental aspects of their environment, they must acquire such an understanding. It is no good to teach when it is the wrong things that are taught. Only in this way will the pattern of dysfunctional academic behavior be broken.

Most library faculty have not been trained in the mentoring process and have little real experience in it. It is therefore imperative that faculty and administrators recognize the need to develop not only mentoring programs for their new library faculty but also to develop faculty who will be able to mentor successfully.

\section{IMPLICATIONS OF THE SOCIALIZATION MODEL}

While nonlibrarian faculty members in their first professorial positions still have much to learn, they have already developed a set of expectations, an understanding of their disciplines' typical modes of operation and inquiry, a set of professional and scholarly ethics, and firsthand experience performing the activities that are rewarded with promotion and tenure. Many or most new academic librarians have also undergone a socialization process and have developed expectations, a set of ethics, and so on, but the socialization process for librarians is different from that for instructional faculty. The process for librarians lacks certain components and emphases found in the process for instructional faculty, and the consequence of these differences is that academic librarians may not be fully prepared to function as faculty. Faculty members are part of a scholarly community because they share a common set of values and beliefs. Shulman has called these values and beliefs the academic model, while Clark regards them as sources of integration. In either case, core values and beliefs serve to unite faculty members and provide focuses that direct faculty activities. Therefore, instructional faculty members from different disciplines may be said to relate similarly to shared values and beliefs. However, there is serious question as to whether librarians relate to the academic model in the same way as do instructional faculty. Specifically, the role of research and scholarship is not so central to the duties of academic librarians as it is to instructional faculty. This is exacerbated by what Steven K. Stoan sees as librarians' and instructional faculty's differing views of information. "The emphasis on information-retrieval techniques that link researchers directly to the ideas, interpretations, suggestions, comments, and views of their peers dovetails neatly with the sizable literature on the intellectual processes involved in research. These studies point to the powerful influence of creative in- 
sight and intuition that come only from a well-instructed mind working continually with the subject matter of the discipline." Despite the popular conception to the contrary, research is normally random, nonlinear, and nonsequential. ${ }^{26}$ Consequently, librarians too often have difficulty thinking as faculty do about knowledge as a dynamic and expanding realm, rather than as an accreting mass to be stored and retrieved. The education of librarians has conditioned them to be myopic, to think in terms of bibliographies, indexes, and abstracts, not in terms of ideas.

\section{Librarians not only are unprepared to meet research requirements ... but also lack an empathetic appreciation for the rigors and methodology of research.}

Undeniably, academic librarians do a considerable amount of scholarly work every day as they carry out their library responsibilities. But in spite of this, they are for the most part out of the faculty research loop. ${ }^{27}$ Studies continue to show that research-and-publication activity is not a central part of the performance expectations for many academic librarians. ${ }^{28}$ Research also indicates that among the competencies deemed necessary for the practice of academic librarianship, research skills are recognized as desirable but are not deemed to be a particularly high priority. ${ }^{29}$ Librarians apparently believe that research, although central to the university's mission, is only to be supported by librarians, not done by them. One returns to the question of whether librarianship is to be thought of as a service profession or an academic discipline.

The concern is not simply that many institutions do not appear to consider librarians to be scholars, but that there are not enough senior librarians trained to do research and to publish, or who have excelled in the faculty model to serve as mentors for the new librarians. It is a chicken-and-egg problem. Barton and Gaughan correctly note that "course work and research are the formal expressions of socialization. ${ }^{\prime 30}$ As long as there is no commitment to the notion that librarians should be required to do research and publish, there will be little incentive for library schools to socialize their students fully to the same kind of scholarly attitude and commitment expected of instructional faculty. But it is in the graduate library schools that academic librarians are formed, nourished, and hatched. There neither can nor will be an immaculate inception of academic faculty attitudes and inclinations among library school students. Library educators must begin tracking potential academic librarians early on so that the students' vision of this particular kind of librarianship is not confused with that of public or special libraries.

If graduate school is the best place for the acculturation of faculty values, then it is disturbing to note research questioning the extent to which library science faculty have absorbed those values. In discussing the results of a survey of graduate library school deans, Mary Kingsbury notes that while the library schools' faculty evaluation criteria emphasize research and teaching, "comments from respondents to this study reveal that many library schools have yet to build a tradition of research and publication." ${ }^{31}$ The impending crisis caused by the graying of library school faculty as discussed by Elizabeth Futas and Fay Zipkowitz provides alternatives for both concern and hope. ${ }^{32}$ There is concern that the entry-level professoriate in the graduate library school is not lucrative to librarians who have built a base of professional experience. The fear is that "the inability to recruit faculty may soon be mirrored in the profession as a whole." ${ }^{33}$

Such a scenario may only serve to exacerbate the current situation described by Kingsbury by compounding it with inexperience or high faculty-to-student ratios. On the other hand, the opportunity presented by entering into a sea-change period in which there will be a greening of graduate library school faculty offers 
the possibility of developing faculty who can provide both positive role models and mentoring opportunities for graduate students who will become faculty librarians.

Undoubtedly, library schools are at a disadvantage when competing for applicants. Few undergraduate library programs act as feeders to the graduate library schools. Moen and Heim have shown that the graying of library school faculty is compounded by the relative maturity (i.e., more than half are over thirty years old) of library school students. ${ }^{34}$ It is natural to inquire whether anything can be done to select applicants who have the potential and interest to become academic librarians and who are fully socialized to the academic model. Nevertheless, the wrong signals are being sent. As long as librarianship is viewed as a core of skills through which can be cycled all prospective librarians

\section{If an academic model is to be} embraced it must be embraced for all that it is-academic freedom, scientific norms, scientific methodology, and the ethics of research and scholarship.

regardless of the kind of librarianship (public, special, or academic) they wish to practice (if they even know), and as long as library educators see no choice but to prepare their students for jobs with the emphasis on providing the tools to compete in the job interview and ultimately gain employment, ${ }^{35}$ librarians will have difficulty in acculturating to the professoriate, and library school faculty and library administrators will continue to give low priority to the intellectual fiber that forms the fabric of the academic environment. If library school faculty members are not inculcating the academic model, for whatever reason, then clearly they are not sanctioning behavior that conforms with the professoriate's characteristic behavior. However, there seems to be no reason why such sanctioning could not be done if library school faculty members chose to do it. The same may not be true for sequestration. Many library school students are of necessity part-time students. They must hold down jobs or help with family responsibilities while completing their studies. Therefore these students have many influences that distract from, if not conflict with, the transmission of the professional values that sequestration promotes. However, this is also certainly true in all disciplines and institutions, and varies in extent or effect based on extenuating factors, such as size of faculty, faculty-to-student ratios, institutional philosophy, tuition levels, and urban-versus-rural geography. If these pressures are not peculiar to library education, why are library science graduate students different from their counterparts in English, political science, or biology? Perhaps it is because librarians fortify themselves with the notion that they are different. They are not, but the myth perpetuated becomes a selffulfilling prophecy.

\section{IMPROVING THE ACCULTURA- TION OF ACADEMIC LIBRARIANS}

There is a temptation to say that the profession must decide whether it is truly committed to the "Standards for Faculty Status" and the sentiments embodied therein, but this is a red herring. What the profession says or thinks really is incidental. There are academic institutions that see advantage to having librarians who are faculty peers. They will set their own standards. Then, of course, some librarians actually prefer being faculty. ${ }^{36}$ They seek out the institutions that offer them the opportunity, and as long as this is the case, librarians, library educators, library administrators, and applicants must each respond in kind. Rather than to continue fruitless discussions about how to act like faculty, it is long past time for librarians to be faculty. To invoke Nike's popular advertising slogan"just do it."

No single prescription exists for solving the malady that infects academic librarianship. Here are some substantive suggestions that, if implemented, will contribute to increasing librarians' confidence and performance as faculty. These suggestions constitute a therapeu- 
tic program, a multifaceted regimen, that, if followed by all participants, may finally treat the pathology at work instead of the symptoms and produce a confident and productive generation of library faculty.

\section{Library Educators}

Clearly, library school professors need to be part of the solution, for they will be instrumental in carrying out the graduate school acculturation process and will serve as role models for novice librarians who intend to become practicing academic librarians with faculty status. Things that those in library education can do are:

- Track M.L.S. students in academic librarianship separate from those pursuing other genres of librarianship. This will allow for more homogeneous concentration on the academic environment and ethos.

- Offer financial enticement in the form of postgraduate fellowships to draw those who already have doctoral or master's degrees into M.L.S. programs. ${ }^{37}$

- Demand substantive evidence of scholarly research and creativity from library school faculty. Provide students with opportunities to participate in faculty research as part of a mentoring process; among other ways, this might be accomplished by budgeting for graduate research assistant positions.

- Require a research thesis for those M.L.S. students pursuing the academic librarianship track. This will provide a solo research experience under the guidance of a committee of faculty. This experience will provide future empathy with nonlibrary faculty, provide some familiarity with research methodology, and sow the seeds of confidence for future scholarly activity.

- Provide formal instruction that addresses the duties and expectations for librarians with faculty status, especially vis-à-vis the areas of research and creativity (including publication), service to the local institution and the profession, and continuing professional and intellectual development. This will re- duce considerably the too-frequentshock experienced by new librarians when confronted by such performance expectations beyond librarianship per se.

- Make the Association of College and Research Libraries instead of the American Library Association the accrediting body for programs that train graduate students for academic librarianship.

It is left to library educators to struggle with the question of whether the aforementioned program can be accomplished through a restructuring of the

\section{Librarians apparently believe that research, although central to the university's mission; is only to be supported by librarians, not done by them.}

current curriculum or whether they must, as have their Canadian colleagues (along with the University of North Carolina at Chapel Hill and the University of California at Los Angeles), go to a two-year M.L.S. program. It is somewhat disturbing to observe the closing of graduate library programs over the past decade. Concern is based not so much on the closures per se, but rather on the fact that most have been at research universities, a phenomenon at cross-purposes with the need for research training for academic librarians.

\section{Library Administrators}

Library administrators bear the responsibility for formulating performance criteria for faculty librarians in accord with general faculty expectations at their institution. To them also falls the responsibility of assuring that their librarians have credibility in their roles as faculty by not assigning them duties that should be performed by support staff. Specific things that the library administrator should do to facilitate acculturation to the faculty model are:

- Clearly express in job announcements the performance expectations for librarians at the institution in question. This will discourage potential 
applicants who are not interested in a faculty position.

- Make clear during employment interviews just what the library faculty performance expectations are. This will discourage candidates who did not fully understand the implications of being faculty as well as encourage those who wish to pursue the faculty model.

- Hire intellect and competence first and foremost. ${ }^{38}$ Intellect and competence will acculturate better and more quickly and will be appreciated by library and nonlibrary colleagues alike. Avoid judging intellect and competence merely by the acquisition of a second graduate degree or the luster of alma mater. However, all other things being equal, opt for additional graduate education.

- Pair the new faculty member with a seasoned librarian who can mentor him or her in regard to organizational and campus culture. This will help acculturate the new librarian to things academic beyond the immediate aspects of librarianship.

- Encourage new faculty who are not confident in the area of research and publication to work with a colleague(s) in collaboration on a project; concomitant with this is encouraging other faculty to be receptive. ${ }^{39}$ If such opportunities are not immediately apparent, encourage the new faculty member to take advantage of the ACRL's mentor program. ${ }^{40}$

- Provide adequate opportunities and support to carry out the kinds and level of scholarship expected of faculty.

- Identify senior faculty who are worthy role models and direct new faculty to the best peer models. Reward senior faculty for serving in this capacity. There must be an understanding that some colleagues may have been "grandfathered" into faculty positions, but have not bought into the faculty model. Special sensitivity will be necessary to assure that the new faculty member does not follow such colleagues as a model in regard to faculty performance expectation in certain areas.

- Recognize and budget adequately for travel and research support so that librarians will be on a level playing field (vis-à-vis support) with other faculty at the institution. This will serve to build morale, increase self-respect, encourage productivity, and diminish excuses.

- Neither tenure nor promote any faculty member who is not worthy. This, over time, will build a solid base of senior faculty role models.

\section{Faculty Librarians}

Once a new librarian comes on the job it is his or her colleagues that will have the greatest daily impact on professional development. It is they who will be observed as models and from whom advice will be sought. The collegiality of the faculty model imparts special responsibilities to colleagues. Things that library peers might do to facilitate acculturation to the faculty model are:

- In the interview process probe deeply for understanding and commitment to the faculty model. Support no candidate who does not show compatible potential.

- Understand the faculty model, be committed to it, and demonstrate this in every professional action. Remember, the cliché has truth-actions do speak louder than words.

- Accept a responsibility to contribute to the development of junior colleagues. This entails taking on the extra work of mentoring them daily on the job or offering to work collaboratively with them on a research or writing project.

- Introduce a new librarian to nonlibrary colleagues in other academic and administrative departments.

- Support no colleague during preliminary, tenure, or promotion review who is not completely worthy. If compassion should prevail instead of responsibility, colleagues, the library, and the university will suffer in both the short and long term.

\section{Applicants}

Applicants who do not understand academe and understand what it means to be faculty and who are not committed to being faculty should not apply for faculty positions. Some things that prospective faculty librarians might do to assure their success in a faculty position are: 
- At the interview inquire about and understand performance expectations and evaluation criteria for annual, intermediate, tenure, and promotion reviews.

- Understand that faculty do not work forty-hour work weeks; usually on-campusand off-campusacademicworkexceeds forty hours. ${ }^{41}$ This means that librarians should not expect release time from a mythical work week in order to do research. ${ }^{42}$

- Be honest with yourself and those who interview you. Admit when a faculty position is not right. Do not become an impostor; impostors are discovered.

- Make sure that you have developed writing and research skills before taking the first faculty position.

- Be committed to the extra librarianship implications of being faculty.

\section{CONCLUSION}

If the academic model is to be embraced it must be embraced for all that it is-academic freedom, scientific norms, scientific methodology, and the ethics of research and scholarship. But valid concerns must be acknowledged that librarians with faculty status may become trapped by the same publish-or-perish quandary that traps other faculty at many institutions. 43 In response to this dilemma, promotion and tenure criteria must encourage and recognize all aspects of scholarship, not just one aspect.

Most faculty members do very little scholarly publishing.44 Librarians can successfully address institutional demands, the desirability of personal and professional intellectual development, and contribute to the growth of knowledge in librarianship or any of the other disciplines. Four kinds of scholarship should be recognized in the promotion and tenure process: scholarship of discovery, of integration, of application, and of teaching. The scholarship of discovery is often called pure and applied research, the pursuit of new knowledge, and is the model of the research-and-publish paradigm on which librarians usually focus when they debate the appropriateness of the faculty model. The scholarship of integration involves synthesizing and interpreting knowledge, giving meaning to isolated data, and providing perspective. The scholarship of application is applying the knowledge of one's own discipline to solving problems of a larger community. The act of application can generate new knowledge and understandings. Finally, good librarianship sparks learning and creative thinking. ${ }^{45} \mathrm{New}$ and different insights can result from different kinds of scholarship.

While there may be legitimacy to the claim that librarians do not do enough scientifically to advance librarianship, it is also true that more could and should be done to integrate and apply what has already been established. The results should be improved library effectiveness, new ideas, new connections between old ideas, and better integration of librarianship with the pedagogy of other disciplines; librarians will gain an intellectual edge. The results must be shared and judged by professional peers, for these acts complete acculturation to the academic model by expanding the librarian's relationship to knowledge. Indeed, the peer review of the tenure and promotion review is a microcosm of this process.

By pursuing any or all of the four kinds of research and creativity librarians will move beyond a storage-and-retrieval relationship with knowledge and become academic in the fullest and most dynamic sense. What is at stake? Tenure? No, it is credibility.

\section{REFERENCES AND NOTES}

1. See Emily Werrell and Laura Sullivan, Faculty Status for Academic Librarians: Annotated Bibliography (Washington, D.C.: Depart. of Education,1985), ERIC Document 274364; see also Werrell and Sullivan's, "Faculty Status for Academic Librarians: A Review of the Literature," College \& Research Libraries 48:95-103 (Mar. 1987); and Kee DeBoer and Wendy Culotta, "The Academic Librarian and Faculty Status in the 1980s: A Survey of the Literature," College \& Research Libraries 48:215-23 (May 1987). 
2. E.g., see Dee Ann Allison and Eva Sartori, "Professional Staff Turnover in Academic Libraries," College \& Research Libraries 49:148-49 (Mar. 1988); ". . when tenure standards do not require it, they [librarians] seem to care little about doing research, rising in rank, or interacting with the teaching faculty. Forcing librarians to behave in the manner of teaching faculty may cause dissatisfaction and thereby contribute to turnover." See also H. Palmer Hall, "Honoring the Contractual Responsibilities of Faculty Status," Journal of Academic Librarianship 16:230-31 (Sept. 1990), for a discussion of the problems created when librarians break faculty contracts during the academic terms.

3. Sandra K. Olson, P. Paul Heppner, Nancy E. Downing, and James Pinkney, "Is There Life after Graduate School? Coping with the Transition to Postdoctoral Employment," Professional Psychology: Research and Practice 17:415 (1986).

4. J.P. Kotter, "The Psychological Contract: Managing the Joining-up Process," California Management Review 15:91 (1973).

5. Association of College and Research Libraries, "Standards for Faculty Status for College and University Librarians," College \& Research Libraries News 33:210-12 (Sept. 1972).

6. Association of College and Research Libraries, "Model Statement of Criteria and Procedures for Appointment, Promotion in Academic Rank, and Tenure for College and University Librarians," College \& Research Libraries News 48:247-54 (May 1987).

7. See William J. Goode, "Community within a Community: The Professions," American Sociological Review 22:194-200 (Apr. 1957).

8. Carol Herrnstadt Shulman, "Old Expectations, New Realities: The Academic Profession Revisited," (Washington, D.C.: American Association for Higher Education, 1979), ERIC document ED 169 874, p.2.

9. Ibid.

10. Burton Clark, "Conclusions," in The Academic Profession, ed. Burton Clark (Berkeley, Calif.: Univ. of California Pr., 1987), p.388-92.

11. See Basil J. Sherlock and Richard T. Morris, "The Evolution of the Professional Paradigm," Sociological Inquiry 37:27-29 (Winter 1967).

12. Herbert S. White, Education for Professional Librarians (White Plains, N.Y.: Knowledge Industry, 1986), p.192.

13. Orville G. Brim, Jr., and Stanton Wheeler, Social ization after Childhood (New York: Wiley, 1966), p. 80; see also Sherlock and Morris, "The Evolution of the Professional Paradigm," 34-35.

14. William E. Moen and Kathleen M. Heim, "The Class of 1988: Librarians for the New Millenium," American Libraries 19:858-60, 885 (Nov. 1988). Of over 3,400 library students in 54 accredited American M.L.S. programs, 56 percent of library students are enrolled part-time. Hypothesizing that full-time students are more likely to be involved in activities that socialize them to their chosen profession, Moen and Heim studied the effect of full-time student status on library organization memberships. Over 60 percent of the library students who were members of ALA were full-time, and 65 percent of the students involved in local student organizations were full-time. By contrast, of the 1,418 students (41 percent of the total) who were not members of any library organizations at the local or national level, 65 percent (921) were part-time students.

15. Sherlock and Morris, "The Evolution of the Professional Paradigm," 35-36.

16. Tony Becher, "The Disciplinary Shaping of the Profession," in The Academic Profession, ed. Burton Clark (Berkeley, Calif.: Univ. of California Pr., 1987), p.283.

17. Ibid., p.283.

18. Ibid., p.282.

19. See Jean-Pierre V. M. Herubel, "The Ph.D. Librarian: A Personal Perspective," College $\mathcal{E}$ Research Libraries News 51:626-28 (July/Aug. 1990), for an insightful discussion of the attributes of an extra-M.L.S. education.

20. William G. Jones, "The Education of Academic Librarians: How Many Degrees Are Enough?" College \& Research Libraries News 52:585-86 (Oct. 1991).

21. See Pauline Wilson, Stereotype and Status (Westport, Conn.: Greenwood, 1982), p.15980.

22. Sherlock and Morris, "The Evolution of the Professional Paradigm," p.37. 
23. Ibid., p.38.

24. Mentoring is not one of the components of the Sherlock and Morris paradigm.

25. Robert G. Sands, L. Alayne Parson, and Josann Duane, "Faculty Mentoring Faculty in a Public University," Journal of Higher Education 62:174-91 (Mar./Apr. 1991); see especially p.185-86 for a detailed rendition of the components and weighing of each component for the four mentoring factors.

26. Steven K. Stoan, "Research and Information Retrieval among Academic Researchers: Implications for Library Instruction," Library Trends 39:248 (Winter 1991).

27. Ibid.

28. For a sampling of the literature on this subject, see Betsy Park and Robert Riggs, "Status of the Profession: A 1989 National Survey of Tenure and Promotion Policies for Academic Librarians," College \& Research Libraries 52:275-89 (May 1991); W. Bede Mitchell and L. Stanislava Swieszkowski, "Publication Requirements and Tenure Approval Rates: An Issue for Academic Librarians," College \& Research Libraries 46:24955 (May 1985); Joyce Payne and Janet Wagner, "Librarians, Publication, and Tenure," College \& Research Libraries 45:133-39 (Mar. 1984); Russ Davidson, Connie Capers Thorson, and Diane Stine, "Faculty Status for Librarians: Querying the Troops," College \& Research Libraries 44:414-20 (Nov. 1983); Thomas G. English, "Librarian Status in the Eighty-Nine U.S. Academic Institutions of the Association of Research Libraries: 1982," College \& Research Libraries 44:199-211 (May 1983); Becky Bolte Gray and Rosalee McReynolds, "A Comparison of Academic Librarians with and without Faculty Status in the Southeast," College \& Research Libraries 44:283-87 (July 1983).

29. See Herbert S. White and Marion Paris, "Employer Preferences and the Library Education Curriculum," Library Quarterly 55:1-33 (Jan. 1985). The researchers surveyed library directors about what the directors thought should be emphasized in the graduate education of librarians; they discovered that although more than half of the respondents indicated the need for a course in academic libraries, less than half recommended courses in research methods. See also Schlessinger et al., "Information Science/Library Science Education Programs in the 1990s," Library Administration \& Management 5:16-19 (Winter 1991), who analyzed recent job advertisements. They found that academic libraries regularly requested resources and information science "orientations," but little was said in the ads about research competencies for fulfilling promotion and tenure criteria. See also, Ronald R. Powell and Sheila D. Creth, "Knowledge Bases and Library Education," College \& Research Libraries 47:16-27 (Jan. 1986); Finally, see Ronald R. Powell, "Sources of Professional Knowledge for Academic Librarians," College \& Research Libraries 49:332-40 (July 1988). Powell asked a sample of ARL librarians to evaluate the relative importance of 56 different knowledge bases. He discovered that research methods ranked twenty-second in importance and inferential statistics ranked fifty-fourth.

30. Barton M. Clark and Thomas M. Gaughan, "Socialization of Library School Students: A Framework for Analysis of a Current Problem," Journal of Education for Librarianship 19:287 (Spring 1979).

31. Mary Kingsbury, "How Library Schools Evaluate Faculty Performance," Journal for Education for Librarianship 22:237 (Spring 1982). Barton and Gaughan also note this phenomenon, p.290.

32. See Elizabeth Futas and Fay Zipkowitz, "The Faculty Vanishes," Library Journal 116:148-52 (Sept. 1, 1991).

33. Ibid., p.152.

34. Moen and Heim, "The Class of 1988," p.860.

35. See Herbert S. White, "New Educational Values and Employability: Closing the Gap," Journal of Academic Librarianship 17:209 (Sept. 1991).

36. Marjorie A. Benedict, "Librarians' Satisfaction with Faculty Status," College \& Research Libraries 52:538-48 (Nov. 1991) gives evidence that faculty status is significantly the preferred status. See also Janet Krompart and Clara DeFelice, "A Review of Faculty Status Survey, 1971-1984," Journal of Academic Librarianship 13:14-18 (Mar. 1987).

37. E.g., the Council on Library Resources's internships for recent graduates. See Deanna Marcum's, "CLR Internships for Recent Graduates," Journal of Academic Librarianship 17:69-70 (May 1991). 
38. Patricia Battin, "Developing University and Research Library Professionals: A Director's Perspective," American Libraries 14:22 (Jan. 1983).

39. For examples of home-grown mentoring programs, see Ilene F. Rockman, "Promoting Professional Development: A Local Approach," College \& Research Libraries News 50:902-4 (Nov. 1989), and Kathleen Kenny, Linda D. Tietjen, and Rutherford W. Witthus, "Increasing Scholarly Productivity among Library Faculty: Strategies for a Medium-sized Library," Journal of Academic Librarianship 16:276-79 (Nov. 1990).

40. The ACRL's mentor program, begun in 1990, is meant to pair senior and experienced researchers and writers with junior members of the profession. Although the program is well-intentioned and addresses a serious need, in view of the deficiencies discussed in this essay, it is compensatory in nature.

41. There are numerous studies to support the understanding that the normal faculty workweek exceeds forty hours: e.g., Higher Education Faculty: Characteristics and Opinions (Washington, D.C.: National Education Association, 1979), ERIC Document 174154; Robert W. Starkey, Faculty Activity Analysis: A Study of Faculty Responsibilities for Instruction, Research, and Public Service (San Diego, Calif.: California University [sic], 1979), ERIC Document 155972; Susan H. Russell et al., Faculty in Higher Education Institutions, 1988 (Washington, DC: National Center for Education Statistics, 1990), ERIC Document 321628; and Larry W. Lacy et al., Activities of Science and Engineering Faculty in Universities and 4-Year Colleges: 1978/79 (Washington, D.C.: National Science Foundation, 1981), ERIC Document 221129.

42. See Robert Boice, "Is Released Time an Effective Component of Faculty Development Programs?" Research in Higher Education 26:311-26 (1987). Released time is not necessarily effective; it is often not used by librarians to do research and scholarly activity even though that was its expressed purpose.

43. Robert Boice, Jordan M. Scepanski, and Wayne Wilson, "Librarians and Faculty Members: Coping with Pressures to Publish," College \& Research Libraries 48:494-503 (Nov. 1987). The authors conclude that both librarians and nonlibrary faculty surveyed used time inefficiently or unproductively, and place a far greater priority on service than on scholarship. Both librarians and nonlibrary faculty displayed a similar resistance to writing.

44. Ernest L. Boyer, Scholarship Reconsidered: Priorities of the Professoriate (Princeton, N.J.: The Carnegie Foundation for the Advancement of Teaching, 1990), p.43-48.

45. Ibid., p.16-25. 